\title{
THE EFFECT OF GADGET AND PARENTING PATTERN ON STUDENTS' SOCIAL BEHAVIOR AT GRADE V AND VI OF SD PREMBULAN PANDOWAN YOGYAKARTA
}

\author{
Kartiwin $^{1}$, Azam Syukur Rahmatullah ${ }^{2}$, Aris Fauzan ${ }^{3}$ \\ ${ }^{1,2,3}$ Universitas Muhammadiyah Yogyakarta, Yogyakarta, Indonesia \\ ${ }^{1}$ kartiwin761@gmail.com, ${ }^{2} a z a m . s y @ u m y . a c . i d,{ }^{3}$ mas_arisfauzan@umy.ac.id
}

\section{PENGARUH PENGGUNAAN GADGET DAN POLA ASUH ORANG TUA TERHADAP PERILAKU SOSIAL SISWA KELAS V DAN VI SD PREMBULAN PANDOWAN YOGYAKARTA}

\begin{abstract}
ARTICLE HISTORY
ABSTRACT

Abstract: This research aimed to identify the influence of gadget and parenting pattern on the students social behavior at grade V and VI of SD Prembanan Prembulan Pandowan Galur Kulon Progo Yogyakarta, as well as to identify which variable was more influential on students'social behavior. This research was quantitative research with a total of 55 students of classes $V$ and VI. The data were collected through interviews and questionnaires. The linear regression test resulted in the value of Sig 0.000 which indicated that gadget and parenting pattern were simultaneously influential on students

Submitted:

10 Juni 2021

$10^{\text {th }}$ June 2021 social behavior; as seen from the percentage of $94.5 \%$. The t-test of the regression analysis resulted in 8.894 which indicated that the variable of gadget gave an influence on the students' social behavior. Whilst its significance amounted at 0.000 which indicated that gadget usage gave influence to students' social behavior to the extent of $69.6 \%$. Furthermore, the t-test on the variable of parenting pattern resulted in 3.323 and the significance value of 0.002 . The results indicated that parenting pattern gave an influence on students' social behavior to the extent of $24.9 \%$
\end{abstract}

Keywords: gadget, parenting pattern, students'social behavior

Accepted:

28 September 2021

$28^{\text {th }}$ September 2021

\begin{abstract}
Abstrak: Penelitian ini mempunyai tujuan untuk mengetahui pengaruh penggunaan gadget dan pola asuh orang tua terhadap perilaku sosial siswa kelas V dan VI SD Prembulan Pandowan Yogyakarta dan variabel mana yang lebih berpengaruh terhadap variabel perilaku sosial siswa. Penelitian ini merupakan penelitian kuantitatif dengan jumlah subjek yaitu 55 siswa kelas V dan VI. Tehnik Pengumpulan data yang digunakan antara lain wawancara, angket dan dokumentasi. Dari analisis regresi linear berganda didapatkan nilai Sig sebesar 0,000 yang menunjukkan bahwa penggunaan gadget dan pola asuh orang tua secara bersama-sama sebesar $94.5 \%$ memberikan pengaruh terhadap perilaku sosial siswa. Hasil uji t dalam analisis regresi diperoleh variabel penggunaan gadget memiliki $t$ hitung sebesar 8,894 dan nilai signifikansi sebesar 0.000 yang artinya penggunaan gadget memberikan pengaruh terhadap perilaku sosial siswa dengan besaran sumbangan $69.6 \%$. Selanjutnya untuk variabel pola asuh orang tua memiliki thitung sebesar 3.323 dan nilai signifikansi sebesar 0,002 yang artinya pola asuh orang tua memberikan pengaruh terhadap perilaku sosial siswa dengan sumbangan sebesar $24.9 \%$
\end{abstract}

Kata Kunci: penggunaan gadget, pola asuh orang tua, perilaku sosial siswa

\section{CITATION}

Kartiwin. Rahamatullah., A., S. \& Fauzan., A. (2021). The Influence of Gadget and Parenting Pattern on Students' Social Behavior at Grade V And VI of SD Prembulan Pandowan Yogyakarta. Primary: Jurnal Pendidikan Guru Sekolah Dasar, 10 (5), 1320-1326. Doi: Http://dx.doi.org/10.33578/jpfkip.v10i5.8430.

\section{PENDAHULUAN}

Pergaulan hidup manusia di masyarakat, dibutuhkan perilaku dan sikap saling menghormati antar individu, saling menghargai, toleransi dan menghormati antara satu dan yang lainnya, dan tidak menghalangi hak individu lain. Perilaku dan sikap tersebut termasuk komponen dari pendidikan karakter yang harus dididik terhadap anak semenjak awal. Selain guru yang harus memberikan pendidikan karakter ini, maka 
orang tua juga seharusnya turut bersama-sama mendidik kualitas karakter pada anak. Sebagaimana yang disampaikan Lickona (2012) bahwa orang tua dan sekolah perlu bekerjasama dalam menanggulangi persoalan menurunnya moralitas anak era sekarang. Dengan adanya kerjasama antara sekolah dan orang tua, diharapkan dapat menambah kualitas moralitas seperti harapan negeri ini. Selanjutnya akan mengarahkan ke perilaku sosial yang baik. Huston (1986) menyampaikan bahwa perilaku sosial mempunyai korelasi saling memberikan pengaruh terhadap kegiatan individu. Dapat dikatakan bahwa aktivitas individu dan perilaku sosial bagaikan dua sisi mata uang yang sulit dipisahkan.

Semakin maju dunia teknologi informasi dan pengaruh arus globalisasi telah menciptakan kepentingan baru untuk manusia. Teknologi dibuat supaya urusan manusia menjadi lebih mudah. Bermacam rupa bentuk teknologi yang tidak dapat dihitung jumlahnya manusia temukan di era sekarang. Gadget merupakan satu contoh teknologi yang sangat popular, setiap orang menggunakan gadget dengan teknologi yang modern seperti televisi, telepon genggam, laptop, komputer, tablet, smart phone. Abdillah (2019) gadget ini dapat ditemui dimanapun, baik pada orang dewasa maupun anak-anak.

Nadhila (2013) mendefinisikan Gadget adalah sebuah istilah dalam bahasa Inggris yang mengartikan sebuah benda (benda atau barang elektronik) teknologi kecil yang memiliki fungsi khusus, tetapi sering diasosiasikan sebagai sebuah inovasi atau barang baru. Pada era teknologi seperti saat ini, kebutuhan gadget adalah salah satu kebutuhan utama. Mulai dari anak sekolah, pengusaha dan lainnya memang sangat membutuhkan perangkat gadget, mulai dari smarthphone, komputer, laptop dan lainnya. Gadget adalah sebuah perangkat elektronik yang berbentuk kecil yang memiliki fungsi khusus. Untuk membedakan dengan perangkat elektronik lain yaitu dari unsur kebaruannya, modelnya dimana dari hari ke hari selalu mencul dengan bentuk yang berfariasi serta menyajikan teknologi terbaru sehingga membuat manusia menjadi bertahan lama bahkan tidak membuat bosan saat menggunakannya. Salah satu diantaranya yang menarik yaitu internet karena manusia dapat mengakses apa yang diinginkan dengan mudah dan praktis untuk memperoleh apa yang dicarinya. Dari itulah dapat memperoleh banyak teman, relasi bisnis, bertemu teman lama atau yang sering disebut reuni serta dapat mencari ilmu dengan cara membuat group whatsApp, twiter, facebook, Instagram.

Noegoroho (2010) Melalui gadget, komunikasi mudah dan murah, serta yang lebih penting adalah bagaimana memanfaatkan gadget untuk mempengaruhi perilaku sosial masyarakat secara lain. Dari berbagai media masa manusia dengan mudah mencari sesuatu yang dikehendaki, cepat mendapatkan informasi, meringankan tenaga dalam mencari penghasilan, memudahkan dalam segala hal sesuai apa yang diinginkan. Dengan modal yang tidak mahal maka manusia sudah dapat berkomunikasi dengan banyak orang, dapat menerima pesan yang lebih singkat tanpa harus bertatap muka dengan orang yang diajak bicara, dapat berkomunuikasi langsung dengan melihat keadaan lawan bicaranya. Semua dipermudah, dipercepat dengan adanya media masa yang ada saat ini. Akibat dari kemajuan tehnologi, handphone telah menjelma sebagai gadget yang multiguna. Arminen dalam Hendrastomo (2008) juga menyampaikan hal yang sama bahwa penggunaan handphone juga berdampak pada perubahan perilaku budaya dan memberi pengaruh pada perilaku relasi sosial antar individu yang kemudian menuju pada proses individualisasi.

Gadget tersebut banyak digunakan dalam keluarga, karena setiap anggota keluarga mayoritas menggunakan teknologi tersebut. Anakanak yang berusia balita, remaja bahkan orang dewasa juga sudah memakai handphone untuk bermain, mengerjakan tugas dari sekolah, mencari informasi, mencari ilmu agama, mendengarkan ceramah, pengajian serta mencari penghasilan pun juga menggunakan gadget, alat komunuikasi.

Dari penjelasan di atas maka peneliti menyimpulkan bahwa gadget merupakan alat komunikasi yang bermanfaat bagi manusia 
dimana gadget berfungsi untuk semua kebutuhan. Hampir setiap individu mempunyai handphone untuk komunikasi sesuai apa yang mereka butuhkan. Setiap hari individu membutuhkan informasi, baik itu berupa berita sosial, suka, duka bahkan berita dari luar negeripun dapat diperoleh. Didalam keluargapun juga dalam berkomunikasi menggunakan alat komunikasi. Sebuah kebutuhan untuk kepentingan dalam bertegur sapa saling mengingatkan antara satu dengan yang lain.

Menurut Sarwono (2011) salah satu yang mempengaruhi perilaku sosial siswa adalah keluarga. Keluarga adalah tempat yang paling penting dalam memberikan pengasuhan anak, karena anak dibesarkan dalam suatu keluarga. Orang tua adalah cerminan diri dari anaknya. Ayah ibu merupakan tauladan bagi anak-anak dapat melihat sesuatu yang ada di sekitarnya. Keluarga juga berpengaruh besar dengan pola asuh orangtua untuk keberlangsungan putra putrinya dalam berperilaku.

Ahmad Tafsir dalam Handayani (2020) memiliki pendapat bahwa pendidikan merupakan arti dari pola. sehingga pola asuh orang tua ialah usaha orang tua yang persisten dan konsisten dalam membimbing dan menjaga anak semenjak lahir. Pola asuh orang tua ialah refleksi yang berkenaan dengan perilaku dan sikap ketika interaksi antara anak dan orang. Saat orang tua memberi pengasuhan, maka orang tua akan memberi disiplin, perhatian, hadiah, hukuman dan peraturan, juga respon dengan apa yang diinginkan anak. Dengan demikian dari pola asuh orangtua maka akan terbentuklah perilaku sosial anak yang akan membuatnya ke jalan yang baik atau yang buruk. Dari apa yang anak dapatkan dikeluarga terbentuklah kepribadian dari usia dini atau sekolah dasar yang menentukan tingkah laku, perbuatan anak dalam bersosialisasi di lingkungan masyarakat dan sekolah.

Chaplin (2006) menyebutkan bahwa perilaku sosial menggambarkan suatu keinginan untuk berperilaku melalui suatu model khusus terhadap individu lain. Dengan kata lain memiliki arti yakni suatu tindakan yang terencana dan bertujuan sosial, sebagai lawan daripada kepentingan sendiri. Apabila perilaku sosial anak dilingkungan baik, maka orangtua dalam memberikan asuhan berdampak baik, namun jika perilaku sosial anak kurang baik atau menyimpang maka dapat dikatakan orangtua dalam memberikan tauladan atau contoh kurang baik. Anak bertingkah laku baik dan tidaknya terpengaruh oleh lingkungan atau orang yang ada disekitar serta pola asuh. Maka dari itu keberhasilan dalam pendampingan orangtua tergantung pada lingkungan dan anak itu sendiri saat menjalaninya.

Hasil wawancara dengan Bapak Teguh Santoso kepala sekolah SD Prembulan bahwa siswa-siswa kelas V dan VI di SD Prembulan Pandowan Galur Kulon Progo Yogyakarta, mayoritas menggunakan gadget sebagai media pembelajaran serta untuk kegiatan lain, seperti game, mencari informasi. Namun realitanya, banyak siswa yang terlalu sibuk dengan gadget nya masing-masing sehingga ini berdampak terhadap perilaku sosialnya. Contohnya saat duduk bersama mereka disibukkan dengan gadget masing-masing yang seharusnya mereka berkomunikasi, canda tawa, bermain tetapi ini tidak mereka lakukan. Maka dari itu disinilah pentingnya peran orangtua untuk memberikan pengasuhan untuk putra putrinya. Mengajarkan bagaimana cara berinteraksi dengan sesama, yang lebih tua, guru maupun dengan masyarakat. Pada kenyataannya di masyarakat perilaku sosial sangat perlu untuk diterapkan tanpa sopan santun serta tata krama maka dalam bersosialisasi akan kurang baik. Pola asuh sangatlah penting untuk pendidikan anak.

\section{METODE PENELITIAN}

Subjek penelitian ini adalah 55 siswa kelas V dan VI SD Prembulan, Kulonprogo, Yogyakarta. Penelitian ini menggunakan pendekatan kuantitatif. Pengumpulan data pada penelitian ini menggunakan metode wawancara dan angket. Wawancara digunakan untuk menggali informasi dari narasumber yaitu kepala sekolah SD prembulan dan beberapa orangtua siswa mengenai realita perilaku siswa di sekolah dan masyarakat. Sedangkan angket dalam penelitian ini yakni angket penggunaan gadget, 
angket pola asuh orangtua dan angket perilaku siswa. Angket adalah sejumlah pertanyaan tertulis yang digunakan untuk memperoleh informasi dari responden dalam arti laporan tentang pribadinya atau hal-hal yang ia ketahui (Arikunto, 2010). Penelitian ini memakai angket dengan metode dalam model skala Likert. (Azwar, 2007)

Teknik analisis data yang digunakan dalam penelitian ini adalah analisis regresi linear berganda. Sebelum melakukan analisis regresi linear berganda, peneliti melakukan uji validitas, uji reliabilitas, uji normalitas, uji linearitas dan uji multikolinearitas (Hadi, 2006).

\section{HASIL DAN PEMBAHASAN}

Fitria dkk (2020) Kemajuan teknologi saat ini juga berpengaruh terhadap perkembangan ilmu pengetahuan. Contohnya pada era sekarang anak terutama siswa yang masih sekolah lebih sering diberikan tugas oleh guru lewat gadget. Contoh lainnya yaitu ketika kegiatan masyarakat kebanyakan generasi milenial saat ini tidak peduli dan mengabaikannya Hal itulah yang menyebabkan penggunaan gadget lebih besar pengaruhnya terhadap perilaku siswa kelas $\mathrm{V}$ dan VI SD Prembulan pada penelitian ini. Siswa lebih banyak menghabiskan waktu sehari-harinya untuk bermain gadget.

Selaras dengan penelitian yang dilakukan oleh Syahyudi (2019). yang menunjukkan dampak negatif dari penggunaan gadget yang dialami siswa yakni kelelahan fisik, malas beraktifitas, konsentrasi belajar berkurang, kecanduan yang mengakibatkan pengeluaran uang untuk membeli pulsa, serta berbagai macam kenakalan yang lain. berkurangnya daya konsentrasi siswa yang hampir $100 \%$ dan malasnya siswa beraktifitas sosial merupakan dampak negatif tertinggi yakni sebesar $81.81 \%$ dari keseluruhan siswa pengguna gadget yang mendapat kuesioner

Hasil penelitian ini juga diperkuat oleh hasil penelitian Sa'ngadah dkk (2020) yang mengungkapkan bahwa ada hubungan antara kecanduan smartphone dengan perkembangan sosial. Semakin tinggi nilai kecanduan smartphone maka perkembangan sosial menjadi lebih rendah. Remaja yang menggunakan gadget

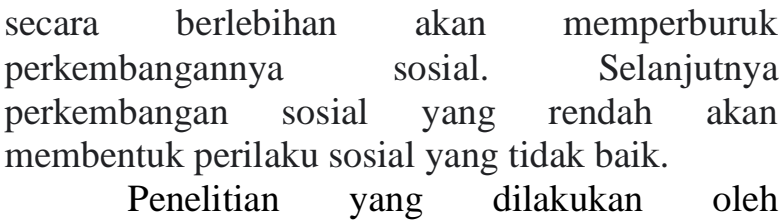
Sulistiawati dkk (2019) yang tujuan penelitiannya ini adalah untuk mengetahui Pengaruh Penggunaan Gadget Terhadap Perkembangan Sosial Anak Pra Sekolah Di Taman Kanak-Kanak Bumi Agung Kecamatan Tegineneng Kabupaten Pesawaran Tahun 2019. Penelitian ini menggunakan desain melalui pendekatan analitik komparatif. Hasil penelitian diperoleh $\mathrm{p}$-value $<\alpha$ $(0,049<0,05)$ yang artinya terdapat pengaruh penggunaan gadget terhadap perkembangan sosial anak prasekolah di Taman Kanak-kanak Desa Karavan Pengadilan Negeri Pesawaran Kabupaten Lampung Tegineneng 2019.

Hasil penelitian ini selaras dengan penelitian yang dilakukan oleh Prayuda, dkk (2020) yang mengungkapkan bahwa pengetahuan pemakaian gadget sangat penting karena akan memberikan pengaruh terhadap perilaku sosial siswa. selanjutnya orangtua dan guru berperan dalam pencegahan perilaku sosial yang negatif. Hal senada juga disampaikan oleh Arminen dalam Hendrastomo (2008) yang menyampaikan jika perubahan perilaku relasi sosial dan perilaku budaya dipengaruhi oleh penggunaan gadget antar individu yang selanjutnya menjadi individualistik.

Pengaruh penggunaan gadget terhadap perilaku sosial siswa juga diperkuat oleh Rahmatullah (2017) dalam penelitiannya yang menunjukkan bahwa penggunaan gadget terdapat pengaruh negatif pada interaksi di dalam keluarga juga berbahaya untuk pertumbuhan serta perkembangan hubungan sosial anak. Anak-anak yang sering dan berulang-ulang menggunakan teknologi digital akan lebih menyedikitkan berinteraksi dengan keluarga intinya bahkan dengan dunia luar sertan memfokuskan diri pada gadget.

Mukaromah, dkk (2020) menjelaskan bahwa manusia adalah makhluk sosial yang artinya tanpa orang lain manusia tidak dapat menjalani kehidupan sehingga membutuhkan bantuan orang lain. Selain itu, salah satu 
kewajiban seorang individu yakni menjaga hubungan baik dengan masyarakat. Hal ini juga berlaku dengan anak. Dalam hal ini orangtua berperan utama untuk membentuk perilaku sosial anak.

Hasil penelitian ini diperkuat juga oleh Sarwono (2011) yang mengungkapkan bahwa salah satu yang mempengaruhi perilaku sosial siswa adalah keluarga. Handayani (2020) menyampaikan bahwa keluarga adalah tempat yang paling penting dalam memberikan pengasuhan anak, karena anak dibesarkan dalam suatu keluarga. Orang tua adalah cerminan diri dari anaknya. Ayah ibu merupakan tauladan bagi anak-anak dapat melihat sesuatu yang ada di sekitarnya. Keluarga juga berpengaruh besar dengan pola asuh orangtua untuk keberlangsungan putra putrinya dalam berperilaku.

Djamarah menjelaskan bahwa ola asuh orangtua merupakan gambaran tentang sikap dan perilaku orang tua dan anak dalam berinteraksi. Dalam memberikan pengasuhan, orang tua akan memberikan perhatian, peraturan, disiplin, hadiah dan hukuman, serta tanggapan terhadap keinginan anaknya. Dengan demikian dari pola asuh orangtua maka akan terbentuklah perilaku sosial anak yang akan membuatnya ke jalan yang baik atau yang buruk. Dari apa yang anak dapatkan dikeluarga terbentuklah kepribadian dari usia dini atau sekolah dasar yang menentukan tingkah laku, perbuatan anak dalam bersosialisasi di lingkungan masyarakat dan sekolah.

Rahmatullah (2017) menjelaskan bahwa keadaan keluarga yang harmonis dapat memberikan pengaruh yang baik pula untuk interaksi anak dan orangtua serta antara anakanaknya. Hal yang demikian pula yang akan membawa kemudahan bagi orang tua dalam mengarahkan anak-anaknya menuju jalan perilaku yang positif. Hal ini juga diperkuat dengan penelitiannya yang menyatakan bahwa orangtua mempunyai tugas utama dalam mendidik serta mengajar anaknya sejak periode prenatal sampai dengan periode pascanatal. Bentuk pendidikan dan pengajaran orangtua di rumah dapat berpengaruh terhadap pembentukan perilaku anak negatif ataupun positif. Hal ini tergantung kualitas pengasuhan dan pendidikan orang tua. Anak akan berperilaku positif manakala pola asuh yang dikembangkan di dalam rumah positif, dan anak akan berperilaku negatif manakala pola asuh yang dikembangkan adalah pola asuh negatif

$$
\text { Selanjutnya Rahmatullah }
$$

menjelaskan bahwa terdapat perilaku-perilaku positif yang terbentuk jika anak memperoleh pola asuh positif yang ditunjukkan dengan pemberian pemenuhan kebutuhan secara batin sejak kecil hingga dewasa yaitu: sikap mengayomi serta welas asih terhadap keluarga juga orang lain dan mudah bergaul. Anak yang memperoleh kebutuhan batin positif yang akan tumbuh menjadi pribadi yang mudah bergaul, supel, dan ramah terhadap siapapun. Hal itu menunjukkan bahwa anak tersebut mempunyai perilaku sosial yang baik.

Nurjannah (2020) dalam penelitiannya mengungkapkan bahwa bimbingan orangtua sebagai pola interaksi antara orang tua dan anak dimana menunjukkan jika kondisinya orangtua memiliki intensitas yang cukup dalam memberikan informasi tentang penggunaan gadget yang sesuai, membantu anak mengidentifikasi dan membedakan perilaku yang pantas dalam menggunakan gadget, memberikan bimbingan dan aturan bagi anak, serta menerapkan disiplin dalam penggunaan gadget, namun orang tua masih minim mengajak anak berkomunikasi tentang aturan dan reward dalam menggunakan gadget. Penelitian yang dilakukan oleh Viandari dan Susilawati (2019) Tujuan penelitian ini untuk mengetahui peran pola asuh orangtua dan penggunaan gadget terhadap interaksi sosial anak pra sekolah. Jumlah Subjek penelitian yaitu 100 anak pra sekolah di Taman Kanak-Kanak Adhi Mekar dan Taman KanakKanak Bintang Besar yang dipilih dengan cara teknik simple random sampling. Instrumen penelitian yakni skala interaksi sosial, skala pola asuh orangtua, dan angket penggunaan gadget. Hipotesis penelitian diuji dengan teknik analysis of covariance (ancova). Hasilnya mengungkapkan nilai sig pada corrected model sebesar 0,000 (p < 0,05), dan kesimpulannya bahwa pola asuh orangtua dan penggunaan gadget secara bersama- 
sama berperan terhadap interaksi sosial anak pra sekolah.

\section{SIMPULAN DAN REKOMENDASI}

Penggunaan gadget dan pola asuh orang tua secara bersama-sama memberikan pengaruh terhadap perilaku sosial siswa dengan tingkat signifikansi $0.000<$ probabilitas 0.05 . Hasil perhitungan SPSS menunjukkan penggunaan gadget mempunyai t hitung 8.894 serta serta nilai Sig. $0.000<$ probabilitas 0.05 . Hal ini berarti penggunaan gadget memberikan pengaruh terhadap perilaku sosial. Semakin positif penggunaan gadget siswa maka perilaku sosial siswa akan semakin tinggi. Sebaliknya semakin negatif penggunaan gadget siswa maka semakin rendah perilaku sosial siswa. Hasil perhitungan SPSS menunjukkan pola asuh orang tua mempunyai t hitung sebesar 3.323 serta nilai Sig. 0.002 < probabilitas 0.05 . Hal ini berarti pola asuh orang tua memberikan pengaruh terhadap perilaku sosial siswa. Semakin positif pola asuh orang tua maka semakin tinggi perilaku sosial siswa. Sebaliknya semakin negatif pola asuh orang tua siswa maka semakin rendah perilaku sosial siswa.

Besarnya sumbangan penggunaan gadget dan pola asuh orang tua terhadap perilaku sosial siswa yakni $94.5 \%$. masih ada variabel-variabel lain sebesar $5.5 \%$ yang mempengaruhi perilaku sosial siswa seperti faktor internal siswa yaitu emosi. Selanjutnya untuk sumbangan efektif penggunaan gadget terhadap perilaku sosial siswa sebesar 69.6\% lebih besar dibandingkan pola asuh orang tua hanya sebesar $24.9 \%$.

Berdasarkan simpulan di atas, maka dikemukakan saran untuk pihak sekolah antara lain supaya dapat meningkatkan perilaku sosial siswa, sekolah dapat melakukan kerjasama dengan pihak-pihak lain dalam bentuk kegiatan parenting atau seminar untuk siswa maupun orang tua.

\section{DAFTAR PUSTAKA}

Aditya, R. P, dkk. (2020). Pengaruh Pemakaian Gadget Terhadap Perilaku Sosial Siswa di Sekolah Dasar Negeri Taal 01 Kecamatan Tapen Kab. Bondowoso. Jurnal
Keperawatan Profesional (JKP), 8(1), 1225.

Abdillah, S. M. (2019). Pengaruh Gadget terhadap Perkembangan Anak. 15(1).

Arikunto, S. (2010). Prosedur Penelitian : Suatu Pendekatan Praktik. Jakarta: Rineka Cipta.

Azwar, S. (2007). Metode Penelitian. Yogyakarta: Pustaka Pelajar.

Rahmatullah, A. S. (2016). Penguatan Perilaku Ngeloni Anak Oleh Orang Tua Sebagai Bentuk Pendidikan Keluarga Harmonis Dan Seimbang. Cendekia, 14(1), 50-65.

Rahmatullah, A. S. (2017) Pendidikan Keluarga Seimbang Yang Melekat Sebagai Basis Yang Mencerahkan Anak Di Era Digital. Cendekia: Jurnal Kependidikan dan Kemasyarakatan, 15 (2), 60-67.

Chaplin, J. P. (2006). Dictionary of Psychology, (Kamus Lengkap Psikologi), Penerjemah: Kartini Kartono. Jakarta: Grafindo

Djamarah, S. B. Pola Asuh Orang Tua dan Komunikasi dalam Keluarga.

Dwinita, K. V. \& Kadek, P.A.S. (2019). Peran pola asuh orangtua dan penggunaan gadget terhadap interaksi sosial anak prasekolah. Jurnal Psikologi Udayana, 6(2), 76-86.

Fitria, dkk. (2020). Pengaruh Penggunaan Gadget Terhadap Perilaku Remaja Dalam Keluarga. Psikoislamedia Jurnal Psikologi, 05(02), 120-137.

Hadi, S. (2006). Metodology Research. Yogyakarta: Andi Offset.

Handayani, L. (2020). Edukasi Pola Asuh Dan Bahaya Penggunaan Gadget. Jurnal Pengabdian kepada Masyarakat UBB, 7(1), 50-65.

Hendrastomo, G. (2008). Representasi Telepon Seluler Dalam Relasi Sosial. Jurnal Sosial Universitas Negeri Yogyakarta, 5(2), 67-80.

Huston, C. A., et.al. (1986). Gender, Adult Srtucturing Of Activities, And Sosial Behavior In Middle Chilhood. JSTOR, 57(5), 80-95. 
Lickona, T. (2012). Educating for character. (Terjemahan Juma Abdu Wamaungo). New York: The New York Times company.(Buku asli diterbitkan tahun 1989)

Mukaromah, F. S., Akif, K., \& Aris, F. (2020). Pola Komunikasi Orang Tua Dalam Pembentukan Kecerdasan Sosial Di Kalangan Remaja Milenia. FOKUS: Jurnal Kajian Keislaman dan Kemasyarakatan, 5(1), 100-120.

Nadhila, I. (2013). Mempermudah Hidup Manusia Dengan Teknologi Modern. Jakarta: Penamadani

Noegoroho, A. (2010). Teknologi Komunikasi. Yogyakarta: Graha Ilmu

Nurjannah, dkk. (2020). Parental Guidance and Its Implications on the Attitudes of Children Aged 7-8 Years of Using Gadgets (Study in Children in Two Large Cities, East Jakarta and Makassar. The Southeast
Asian Journal of Early Childhood Care Education and Parenting, I(1), 100-120.

Sa'ngadah, N, Yuni, S, A., \& Ilya, K. (2020). Gadgets Addiction Behavior Towards Sosial Development In Adolescents. EurAsian Journal of BioSciences Eurasia J Biosci, 14, 27-35.

Sarwono, S. W. (2011). Psikologi Remaja. Jakarta: Raja Grafindo Persada

Sulistiawati, Y., Supratman, V. A., dan Nugroho, T. A. (2019). Pengaruh Penggunaan Gadget Terhadap Perkembangan Sosial Anak Pra Sekolah Di Kabupaten Pesawaran Lampung. Wellness and Healthy Magazine, 1(2), 35-45.

Syahyudi, D. (2019). Pengaruh Gadget terhadap Pola Interaksi Sosial dan Komunikasi Siswa. Jurnal Kehumasan, 2(1), 200220. 